\title{
Physiologic Regulation of the Serum Concentration of 1,25-Dihydroxyvitamin D by Phosphorus in Normal Men
}

Anthony A. Portale, Bernard P. Halloran, and R. Curtis Morris, Jr. General Clinical Research Center, Departments of Pediatrics and Medicine, University of California, San Francisco, California 94143; and Veterans Administration Medical Center, San Francisco, California 94143

\begin{abstract}
We asked this question: in normal humans, is either a normal dietary intake or normal serum concentration of phosphorus a determinant of the serum concentration of $1,25(\mathrm{OH})_{2} \mathrm{D}$ ? In seven normal men whose dietary phosphorus was decreased from 2,300 to $625 \mathrm{mg} / \mathrm{d}$, each intake for 8-9 d, under strictly controlled, normal metabolic conditions, we measured serum concentrations of $1,25(\mathrm{OH})_{2} \mathrm{D}$ daily, and concentrations of phosphorus hourly throughout a 24-h period, before and after restriction. Decreasing dietary phosphorus induced: (a) a 58\% increase in serum levels of $1,25(\mathrm{OH})_{2} \mathrm{D}$; (b) a $35 \%$ decrease in serum levels of phosphorus measured in the afternoon; $(c)$ a $12 \%$ decrease in the 24-h mean serum level of phosphorus; but, (d) no decrease in morning fasting levels of phosphorus. Serum concentrations of $1,25(\mathrm{OH})_{2} \mathrm{D}$ varied inversely and significantly with 24-h mean concentrations of phosphorus ( $r$ $=-0.77, P<0.001)$. When these data are combined with those of our prior study in which dietary phosphorus was varied over an extreme range, the relationship between serum levels of $1,25(\mathrm{OH})_{2} \mathrm{D}$ and 24-h mean serum levels of phosphorus is even stronger $(r=-0.90, P<0.001)$. In the aggregate, the results demonstrate that in normal men, dietary phosphorus throughout a normal range and beyond, can finely regulate the renal production and serum concentration of $1,25(\mathrm{OH})_{2} \mathrm{D}$, and provide evidence that this regulation is mediated by fine modulation of the serum concentration of phosphorus.
\end{abstract}

\section{Introduction}

The renal synthesis of $1,25(\mathrm{OH})_{2} \mathrm{D}$, the most biologically active metabolite of vitamin $D$, is catalyzed by 25 -hydroxyvitamin $\mathrm{D} \alpha$-1-hydroxylase (1-hydroxylase) ${ }^{1}(1-7)$, an enzyme that can be stimulated by PTH (8-14) and suppressed by $1,25(\mathrm{OH})_{2} \mathrm{D}(10,12,13,15)$, normal vitamin $\mathrm{D}$ status (14), blood ionized calcium $(10,16-18)$, and some function of the

This work was presented in part at the National Meeting of the American Society of Nephrology, December 1987.

Address reprint requests to Dr. Portale at 1202 Moffitt Hospital, University of California at San Francisco, San Francisco, CA 941430126.

Received for publication 12 October 1988 and in revised form 28 December 1988.

1. Abbreviations used in this paper: 1-hydroxylase, 25-hydroxyvitamin D $\alpha-1$ hydroxylase; PR, production rate; 25-OHD, 25-hydroxyvita$\min \mathrm{D}$.

J. Clin. Invest.

(c) The American Society for Clinical Investigation, Inc.

0021-9738/89/05/1494/06 $\$ 2.00$

Volume 83, May 1989, 1494-1499 dietary intake of inorganic phosphorus (19-21), perhaps its serum concentration $(11,19)$. In normal humans, severe restriction of dietary phosphorus $(<100 \mathrm{mg} / \mathrm{d})$ induces a large increase in the serum concentration of $1,25(\mathrm{OH})_{2} \mathrm{D}(22-26)$, and supplementation of dietary phosphorus $(>3,000 \mathrm{mg} / \mathrm{d})$, a substantial decrease (26). These changes in serum concentration of $1,25(\mathrm{OH})_{2} \mathrm{D}$ are accounted for entirely by changes in its production rate (PR) (26). We recently reported that with such extreme manipulation of dietary phosphorus in normal men, the changes induced in the PR and serum concentration of $1,25(\mathrm{OH})_{2} \mathrm{D}$ varied inversely with those induced in the 24-h mean serum concentration of phosphorus (27). We suggested that diet-induced changes in serum levels of phosphorus occurring throughout much of the day mediate the changes in $\mathrm{PR}$ and serum concentration of $1,25(\mathrm{OH})_{2} \mathrm{D}$.

Tieder et al. recently proposed that phosphorus may be a "fine modulator" of $1,25(\mathrm{OH})_{2} \mathrm{D}$ production in humans, based upon their finding of a significant inverse relationship between morning fasting serum levels of phosphorus and $1,25(\mathrm{OH})_{2} \mathrm{D}$ in a group of subjects composed of patients with hereditary hypophosphatemic rickets and hypercalciuria, their relatives with hypercalciuria alone, and normal subjects (28). However, in that study, as in the earlier study of Gray et al. (22), the observed inverse relationship depends on the inclusion of values from patients with hypercalciuria whose concentrations of serum phosphorus and $1,25(\mathrm{OH})_{2} \mathrm{D}$ were abnormally decreased and increased, respectively. When only those values from normal subjects are considered, no relationship is apparent in either study. The question thus remains: in normal humans, is either a normal dietary intake of phosphorus or normal serum concentration of phosphorus a determinant of the metabolism of $1,25(\mathrm{OH})_{2} \mathrm{D}$ ? The results of the present study of normal men studied under strictly controlled, normal metabolic conditions, demonstrate that decreasing dietary phosphorus within a normal range increases the serum concentration of $1,25(\mathrm{OH})_{2} \mathrm{D}$ within its normal range, and decreases the serum concentration of phosphorus throughout much of the day, but not in the morning fasting period, and not to frankly reduced values. The results demonstrate that in normal men, normal dietary intakes of phosphorus regulate the serum concentration of $1,25(\mathrm{OH})_{2} \mathrm{D}$, presumably by regulating its renal production, and provide evidence that the regulation is mediated through dietary modulation of the serum concentration of phosphorus.

\section{Methods}

We studied seven healthy men, ages 21-33 yr. All studies were performed at the General Clinical Research Center under a protocol approved for use by the Committee on Human Research, University of California at San Francisco. Informed consent was obtained from each subject. 
Throughout the study, each subject received a constant whole food diet that provided, by calculation, $550 \mathrm{mg}$ of phosphorus, $170 \mathrm{mg}$ of calcium, $85 \mathrm{mg}$ of magnesium, and $80 \mathrm{meq}$ of sodium per $70 \mathrm{~kg}$ body wt/d for $17 \mathrm{~d}$. (Dietary intakes are subsequently expressed per $70 \mathrm{~kg}$ body weight.) The intakes of calcium and magnesium were maintained at 850 and $350 \mathrm{mg} / \mathrm{d}$, respectively, by supplementing the diet with orally administered calcium carbonate and magnesium sulfate. For the first $9 \mathrm{~d}$, the intake of phosphorus was maintained near the upper limit of the normal range, $2,300 \mathrm{mg} / \mathrm{d}$, by administering $1,750 \mathrm{mg} / \mathrm{d}$ of supplemental phosphorus as neutral sodium and potassium phosphate (4:1 mixture of $\mathrm{Na}_{2} \mathrm{HPO}_{4} / \mathrm{K}_{2} \mathrm{HPO}_{4}$ and $\mathrm{NaH}_{2} \mathrm{PO}_{4} / \mathrm{KH}_{2} \mathrm{PO}_{4}, 31 \mathrm{mg}$ phosphorus, $0.9 \mathrm{meq}$ sodium, and $0.9 \mathrm{meq}$ potassium $/ 5 \mathrm{ml}$ ), in divided doses with meals. For the next $8 \mathrm{~d}$, phosphorus intake was decreased to $625 \mathrm{mg} / \mathrm{d}$, the lower limit of the normal range, by replacing the sodium and potassium phosphate supplement with an equimolar amount of sodium and potassium chloride $(0.9 \mathrm{meq}$ sodium and 0.9 meq potassium per $5 \mathrm{ml}$ ). Phosphorus intakes of 2,300 and $625 \mathrm{mg} / \mathrm{d}$ are approximately the 90th and the 5th percentile values, respectively, for healthy men 25-44 yr of age ingesting typical diets (29). The basic diet provided, by calculation, $2,600 \mathrm{kcal} / \mathrm{d}, 9 \%$ as protein, $34 \%$ as fat, and $57 \%$ as carbohydrate. Meals were offered each day at 0900,1230 , and $1715 \mathrm{~h}$.

Arterialized venous blood was drawn without stasis each day before breakfast at $0830 \mathrm{~h}$ for measurement of serum concentrations of phosphorus, total calcium, creatinine, $1,25(\mathrm{OH})_{2} \mathrm{D}$, and immunoreactive (i) PTH, and whole blood concentrations of ionized calcium. Spontaneously voided urine was collected daily in 24-h pools for measurement of concentrations of calcium, phosphorus, creatinine, and cAMP. On the eighth day of the high-normal phosphorus intake and on the fifth day of the low-normal intake, blood was drawn from an indwelling venous catheter at 1-h intervals for $24 \mathrm{~h}$ beginning at $0800 \mathrm{~h}$ for measurement of serum concentrations of phosphorus and total calcium, and at $0900,1100,1500$, and $1600 \mathrm{~h}$ for measurement of blood ionized calcium and serum iPTH concentrations. In two subjects, blood was drawn only from 0800 to $1800 \mathrm{~h}$. At the end of the high-normal phosphorus period, the serum concentration of 25 -hydroxyvitamin D (25-OHD) was measured.

Laboratory methods. Serum concentrations of $1,25(\mathrm{OH})_{2} \mathrm{D}$ were measured in duplicate using a competitive protein binding assay (30) using intestinal cytosol from normal vitamin D-replete chicks. All determinations of serum $1,25(\mathrm{OH})_{2} \mathrm{D}$ for each subject were made in a single assay. Minimum detection limits are $<5$ pg per assay tube; overall recovery ranged from 60 to $70 \%$. Inter- and intraassay coefficients of variation of $1,25(\mathrm{OH})_{2} \mathrm{D}$ in serum were 13.4 and $12.6 \%$, respectively, at a concentration of $31 \mathrm{pg} / \mathrm{ml}$. Serum concentrations of 25-OHD were measured as previously described (31). Serum concentrations of intact iPTH were measured in duplicate by immunoradiometric assay (Nichols Institute, San Juan Capistrano, CA); intraassay coefficient of variation was $<6 \%$. Serum and urinary concentrations of calcium were measured by atomic absorption spectrophotometry, serum and urinary phosphorus by a modification of the Fiske-Subbarow method (32), urinary creatinine by autoanalyzer, and urinary concentration of cAMP in duplicate by RIA (Immuno Nuclear Corp., Stillwater, MN). Whole blood concentrations of ionized calcium were measured in triplicate using the ionized calcium/ $\mathrm{pH}$ analyzer (model 8; Nova Biomedical, Newton, MA). The within-day $(n=17)$ and between-day $(n=40)$ coefficients of variation of ionized calcium determined using aqueous controls were $<2 \%$.

Data analysis. Data are presented as group means \pm SEM. Statistical analysis was performed using the paired $t$ test. Correlation coefficients were calculated by the method of least squares.

Time series analysis. The serum concentrations of phosphorus and calcium, measured throughout each 24-h period on each of the two intakes of phosphorus, were analyzed in a manner similar to that recommended by van Cauter (33) as we previously described (27). Briefly, the 24-h mean serum concentration of each mineral was calculated for each subject for each 24 -h period studied. The variation in concentration over time (time series) for each individual was subjected to spectral analysis $(34,35)$, using a computer program provided as part of the SAS system (Statistical Analysis Systems Institute, Inc., Cary, NC). The time series is described as a sum of sinusoidal functions of different amplitudes and periodicities (periodogram calculation), and those periodicities that contribute significantly to the observed variation were selected using a test procedure as described by Fuller with a minimum probability of $90 \%$ (35). The significant periodic components were used to construct a theoretical curve that describes the data. The circadian acrophase and nadir are, respectively, the times of occurrence of maxima and minima of the theoretical curve; its circadian amplitude is calculated as one-half the difference between its maximum and minimum values, and expressed in absolute concentration units (absolute amplitude) or as a percentage of the 24-h mean level (relative amplitude).

\section{Results}

When dietary phosphorus was decreased from the high-normal to the low-normal intake, the serum concentration of $1,25(\mathrm{OH})_{2} \mathrm{D}$ increased significantly within $48 \mathrm{~h}$ in each subject; thereafter, the values appeared to trend upward slightly (Fig. 1). With the decrease in dietary phosphorus, the mean value of $1,25(\mathrm{OH})_{2} \mathrm{D}$ increased from $29 \pm 4$ to $43 \pm 4 \mathrm{pg} / \mathrm{ml}$ (mean of last $3 \mathrm{~d}$ of each dietary period, $P<0.005$ ), an increase of $58 \pm 15 \%$.

When dietary phosphorus was at high-normal levels $(2,300$ $\mathrm{mg} / \mathrm{d}$ ), the serum concentration of phosphorus exhibited a circadian rhythm characterized by a nadir at 0900 , a rapid rise to a maximum (acrophase) at $\sim 1400$, a decrease to a minor nadir at $\sim 2000$, and subsequent rise to a minor peak at 0100 $h$ (Fig. 2). Spectral analysis demonstrated that in each of the five subjects so studied, significant peaks in phosphorus concentration occurred at 1300-1500 and again at 0100-0300 h; in four subjects, the major peak (acrophase) occurred in the afternoon, and in the other subject, at night. The mean circadian amplitude, calculated from the theoretical curve, was $1.0 \pm 0.2 \mathrm{mg} / \mathrm{dl}$ (absolute), or $24.3 \pm 4.2 \%$ (relative).

When dietary phosphorus was decreased to low-normal levels $(625 \mathrm{mg} / \mathrm{d})$, serum levels of phosphorus throughout most of the day, and thus the 24-h mean level of phosphorus, were significantly lower than the values observed with the higher intake of phosphorus (Fig. 2). At $1400 \mathrm{~h}$, the phosphorus level decreased by $1.4 \pm 0.3 \mathrm{mg} / \mathrm{dl}$, nearly three times the decrease in the 24-h mean level, as compared with values on the higher phosphorus intake. The morning fasting level of phosphorus, however, did not decrease (Table I). By spectral analysis, a nocturnal peak (acrophase) in phosphorus concentration was present in each of the five subjects, occurring at $\sim 2400$, the nadir $(2.6 \pm 0.2 \mathrm{mg} / \mathrm{dl})$ occurring at $\sim 1100 \mathrm{~h}$. With the lower dietary phosphorus, a significant afternoon

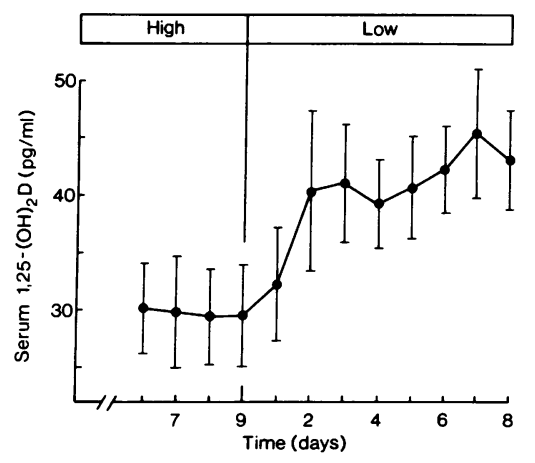

Figure 1. Effect of decreasing dietary phosphorus within its normal range on the daily serum concentration of $1,25(\mathrm{OH})_{2} \mathrm{D}$ in seven normal men. Dietary phosphorus was first maintained at 2,300 $\mathrm{mg} / \mathrm{d}$ for $9 \mathrm{~d}$, then decreased to $625 \mathrm{mg} / \mathrm{d}$ for $8 \mathrm{~d}$. Depicted are mean values \pm SEM. 


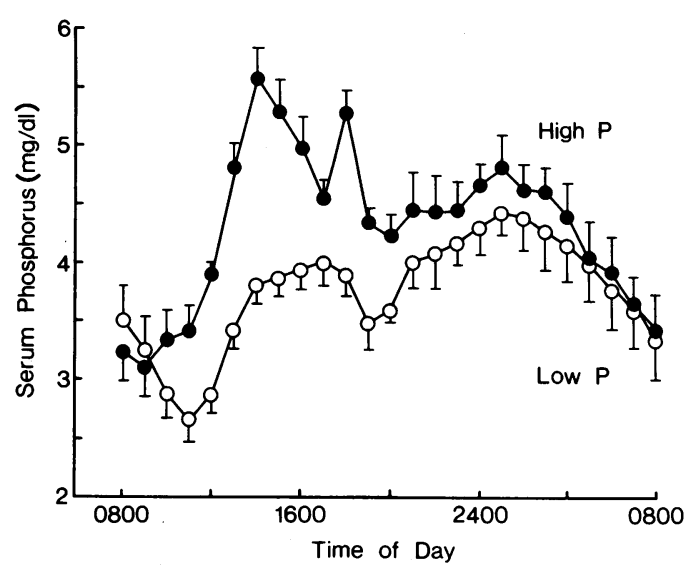

Figure 2. Effect of changes in dietary phosphorus within the normal range on the circadian rhythm in serum phosphorus concentration in normal men. Blood was drawn at hourly intervals for $24 \mathrm{~h}$ beginning at 0800 , on the eighth day of the high-normal $(2,300 \mathrm{mg} / \mathrm{d})$ phosphorus intake and on the fifth day of the low-normal $(625 \mathrm{mg} / \mathrm{d})$ intake. With the lower intake of phosphorus, serum levels of phosphorus were significantly lower during much of the day, particularly in the afternoon, than with the higher intake of phosphorus.

peak was present in only one subject. Thus, decreasing dietary phosphorus decreased the magnitude of the afternoon peak in serum phosphorus so that the peak was no longer significant by spectral analysis (Fig. 2). The mean circadian amplitude was $0.7 \pm 0.1 \mathrm{mg} / \mathrm{dl}$ (absolute), or $17.9 \pm 2.2 \%$ (relative), values slightly but not significantly lower than those on the high-normal intake of phosphorus.

When the values obtained on both the high- and the lownormal intakes of phosphorus were analyzed as a single set, the serum concentrations of $1,25(\mathrm{OH})_{2} \mathrm{D}$ varied inversely and significantly with the 24-h mean serum concentrations of phosphorus $\left(r=-0.77, P<0.001\right.$, Fig. 3). ${ }^{2}$ The relationship between serum levels of $1,25(\mathrm{OH})_{2} \mathrm{D}$ and morning fasting serum levels of phosphorus was much weaker $(r=-0.47, P=0.043)$.

In six healthy men we previously studied under metabolic conditions identical to those of this study, whose dietary phosphorus was maintained first at $1,500 \mathrm{mg}$, then $<50 \mathrm{mg}$, and then $>3,000 \mathrm{mg}$ per $\mathrm{d}$, each for $10 \mathrm{~d}$, serum levels of $1,25(\mathrm{OH})_{2} \mathrm{D}$ ranged from 20 to $90 \mathrm{pg} / \mathrm{ml}$, and 24-h mean levels of phosphorus from 1.0 to $5.2 \mathrm{mg} / \mathrm{dl}$ (27). When data from that study and this one were analyzed as a single set, the inverse relationship between serum levels of $1,25(\mathrm{OH})_{2} \mathrm{D}$ and 24-h mean serum levels of phosphorus was even stronger $(r$ $=-0.90, P<0.001$, Fig. 4). The slope of this relationship in the former study $(y=-17+107)$ is not different from that in this study $(y=-17 x+106)$.

In this study, manipulation of dietary phosphorus induced no significant change in either the fasting or the 24-h mean

2. In the five subjects whose serum levels of phosphorus were determined hourly for $24 \mathrm{~h}$, their 24-h mean serum concentration of phosphorus correlated significantly with their $10-\mathrm{h}$ mean concentration of phosphorus (determined from 0800 to 1800 ) for each intake of phosphorus: high-normal intake; 24 -h mean $=(10-\mathrm{h}$ mean -0.05$) / 0.965, r$ $=0.92$; low-normal intake; 24 -h mean $=(10-\mathrm{h}$ mean +0.27$) / 0.976, r$ $=0.98$. Accordingly, in the two subjects whose serum phosphorus levels were determined for $10 \mathrm{~h}$ ( 0800 to 1800$)$, their 24 -h mean concentration of phosphorus was calculated from the above relationships. serum concentrations of total calcium, or in the concentrations of blood ionized calcium at either $0900,1100,1500$, or $1600 \mathrm{~h}$; the serum concentrations of iPTH at these time points were slightly but not significantly higher with the higher phosphorus intake (data not shown). When dietary phosphorus was decreased, 24-h urinary excretion of phosphorus decreased as expected, urinary excretion of calcium doubled, and urinary cAMP did not change significantly (Table I), nor did 24-h creatinine clearance. The serum concentration of 25-OHD, measured when dietary phosphorus was at high-normal levels, was $18 \pm 2 \mathrm{ng} / \mathrm{ml}$. We previously reported that with extreme manipulation of dietary phosphorus, the serum concentration of 25-OHD did not change significantly (26).

\section{Discussion}

The results of this study demonstrate that in healthy men, decreasing dietary phosphorus within its normal range, from 2,300 to $625 \mathrm{mg} / \mathrm{d}$, induces a rapid and sustained increase in the serum concentration of $1,25(\mathrm{OH})_{2} \mathrm{D}$. Within a week of initiating the lower dietary phosphorus, serum levels of $1,25(\mathrm{OH})_{2} \mathrm{D}$ increased by $58 \%$, from a mean of 29 to $43 \mathrm{pg} / \mathrm{ml}$, values within a normal range (Fig. 1). We previously reported that in normal men in whom dietary phosphorus was severely restricted from 1,500 to $<50 \mathrm{mg} / \mathrm{d}$ for $10 \mathrm{~d}$, serum levels of $1,25(\mathrm{OH})_{2} \mathrm{D}$ increased by $80 \%$ to values clearly outside a normal range (26). Thus, these findings provide evidence that in normal men, under normal metabolic and physiologic conditions, normal dietary intakes of phosphorus can regulate the serum concentration of $1,25(\mathrm{OH})_{2} \mathrm{D}$ within its normal range, presumably by regulating its renal production (26).

The results of this study demonstrate that in normal men, normal dietary intakes of phosphorus can modulate the circadian rhythm in serum concentration of phosphorus: decreasing dietary phosphorus within a normal range induced a substantial decrement in the serum concentration of phosphorus, but only after the morning fasting period. With the lower intake of phosphorus, serum levels of phosphorus during the afternoon were as much as $35 \%(1.4 \mathrm{mg} / \mathrm{dl})$ lower than those occurring with the higher intake, nearly three times the $12 \%$ decrease observed in the 24-h mean level (Fig. 2). These results confirm our previous observation that changes in dietary phosphorus that induce little or no change in morning fasting serum levels of phosphorus can induce substantial changes in these levels during much of the day (27), in particular, during the afternoon. As judged from spectral analysis, with highnormal dietary phosphorus, the variation in serum phosphorus concentration can be described as the sum of sinusoidal functions with periodicities of 24 and $12 \mathrm{~h}$, the acrophase occurring in early afternoon and a lesser peak occurring just after midnight. Decreasing dietary phosphorus decreased the magnitude of the afternoon rise in phosphorus level so that it was no longer significant by spectral analysis; the nocturnal peak in phosphorus level, however, persisted. These data are in accord with our previous observations that the nocturnal rise in phosphorus concentration occurs independently of the intake of phosphorus, whereas the afternoon rise in phosphorus concentration is critically modulated by the intake of phosphorus.

In this study, the serum concentrations of $1,25(\mathrm{OH})_{2} \mathrm{D}$ varied inversely and significantly with the 24-h mean serum 
Table I. Effect of Decreasing Dietary Phosphorus within a Normal Range on Blood and Urine Composition in Normal Men

\begin{tabular}{|c|c|c|c|c|c|c|c|c|c|}
\hline \multirow{2}{*}{$\begin{array}{l}\text { Phosphorus } \\
\text { intake }\end{array}$} & \multicolumn{2}{|c|}{ Serum phosphorus } & \multicolumn{2}{|c|}{ Serum total calcium } & \multirow{2}{*}{$\frac{\begin{array}{c}\text { Blood } \\
\text { ionized } \\
\mathrm{Ca}^{2+}\end{array}}{\text { Fasting }}$} & \multirow[t]{2}{*}{$\begin{array}{l}\text { Serum } \\
\text { intact } \\
\text { iPTH } \\
\end{array}$} & \multicolumn{3}{|c|}{ Urinary excretion } \\
\hline & 24-h mean & Fasting & 24-h mean & Fasting & & & $\mathrm{Ca}$ & $\mathbf{P i}$ & cAMP \\
\hline$m g / d$ & & & $m g / d l$ & & & $p g / m l$ & & $24 h$ & $\mathrm{nmol} / 100 \mathrm{ml} \mathrm{GF}$ \\
\hline $\operatorname{High}(2,300)$ & $4.3 \pm 0.2$ & $3.3 \pm 0.2$ & $10.0 \pm 0.1$ & $10.1 \pm 0.1$ & $4.60 \pm 0.05$ & $23 \pm 4$ & $142 \pm 21$ & $1,539 \pm 85$ & $2.25 \pm 0.22$ \\
\hline Low (625) & $3.8 \pm 0.2$ & $3.6 \pm 0.2$ & $9.9 \pm 0.1$ & $10.1 \pm 0.1$ & $4.60 \pm 0.05$ & $19 \pm 3$ & $289 \pm 35$ & $455 \pm 16$ & $2.17 \pm 0.21$ \\
\hline$\Delta$ & $-0.5 \pm 0.1$ & $+0.3 \pm 0.1$ & $-0.1 \pm 0.1$ & $-0.05 \pm 0.1$ & $0 \pm 0.04$ & $-4 \pm 2$ & $+147 \pm 18$ & $-1,084 \pm 80$ & $-0.08 \pm 0.08$ \\
\hline$P$ & $<0.001$ & $<0.02$ & NS & NS & NS & NS & $<0.001$ & $<0.001$ & NS \\
\hline
\end{tabular}

Values are means $\pm \mathrm{SEM}, n=7$. Values used in calculation of the means are the average of three separate determinations made on each of the last $3 \mathrm{~d}$ of each dietary period, except for the 24-h mean values of serum phosphorus and calcium, which are the average of all 24 determinations made hourly during a $24-\mathrm{h}$ period in each subject, on each diet.

concentrations of phosphorus, when the values on both the high- and the low-normal intakes of phosphorus were analyzed as a single set $(r=-0.77, P<0.001$, Fig. 3). The relationship between serum levels of $1,25(\mathrm{OH})_{2} \mathrm{D}$ and morning fasting levels of phosphorus was much weaker $(r=-0.47, P=0.043)$. When the data of the present study are combined with those from our prior study (27) of normal men in whom dietary phosphorus was manipulated over an extreme range from $\sim$ zero to $>3 \mathrm{~g}$ per day, the serum concentrations of $1,25(\mathrm{OH})_{2} \mathrm{D}$ that extended over a fourfold range, vary inversely and significantly with the 24-h mean serum concentrations of phosphorus which extended over a fivefold range ( $r$ $=-0.90, P<0.001$, Fig. 4). In the aggregate, the results provide strong evidence that in normal men, dietary phosphorus throughout a normal range and beyond, finely regulates the renal production and serum concentration of $1,25(\mathrm{OH})_{2} \mathrm{D}$, at least in part, by finely modulating the serum concentration of phosphorus.

Calvo et al. recently reported that in normal adult subjects in whom dietary phosphorus was increased from 930 to 1,660

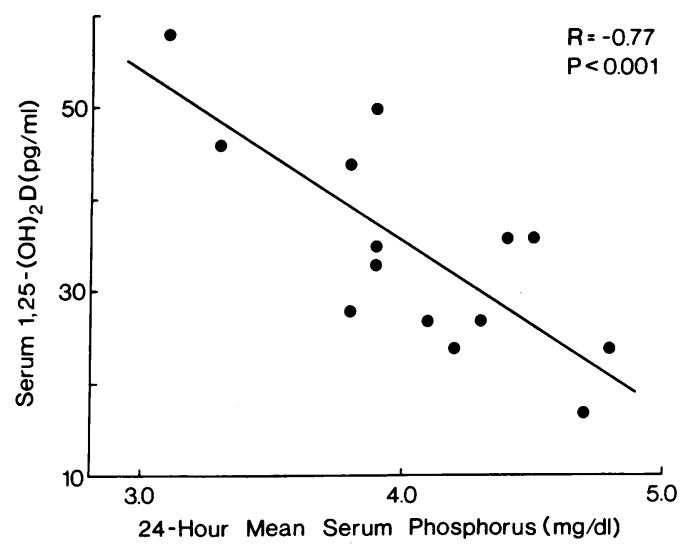

Figure 3. The relationship between serum levels of $1,25(\mathrm{OH})_{2} \mathrm{D}$ and 24-h mean serum levels of phosphorus in seven normal men in whom dietary phosphorus was maintained at either 625 or 2,300 $\mathrm{mg} / \mathrm{d}$. For each point depicted, the value of serum $1,25(\mathrm{OH})_{2} \mathrm{D}$ is the average of two determinations made, one at the beginning and one at the end of the 24-h period during which serum phosphorus was measured hourly; the value of serum phosphorus is the average of all 24 determinations made throughout that period. $\mathrm{mg} / \mathrm{d}$, and dietary calcium simultaneously decreased from 820 to $420 \mathrm{mg} / \mathrm{d}$, achieved by ingestion of whole-food diets containing differing amounts of calcium and phosphorus, the serum concentration of $1,25(\mathrm{OH})_{2} \mathrm{D}$ increased by $11 \%$ in women and $30 \%$ in men (36). The authors proposed that the decreased calcium intake induced hypocalcemia and an increase in serum levels of iPTH (and urinary cAMP), which stimulated the renal production of $1,25(\mathrm{OH})_{2} \mathrm{D}$, and that this effect overrode any suppressive effect that might otherwise have been induced by the small increase in dietary phosphorus and in afternoon serum levels of phosphorus. In this study, in which the diet and intake of calcium remained constant and normal throughout, the suppressive effect of phosphorus on the serum level of $1,25(\mathrm{OH})_{2} \mathrm{D}$ was not opposed by any decrease in blood ionized calcium or any increase in serum iPTH (or urinary excretion of cAMP). In patients with idiopathic hypercalciuria, primary hyperparathyroidism, and moderate renal insufficiency, supplementation of dietary phosphorus induces a decrease in serum levels of $1,25(\mathrm{OH})_{2} \mathrm{D}$ despite inducing a further increase in serum levels of iPTH, and when

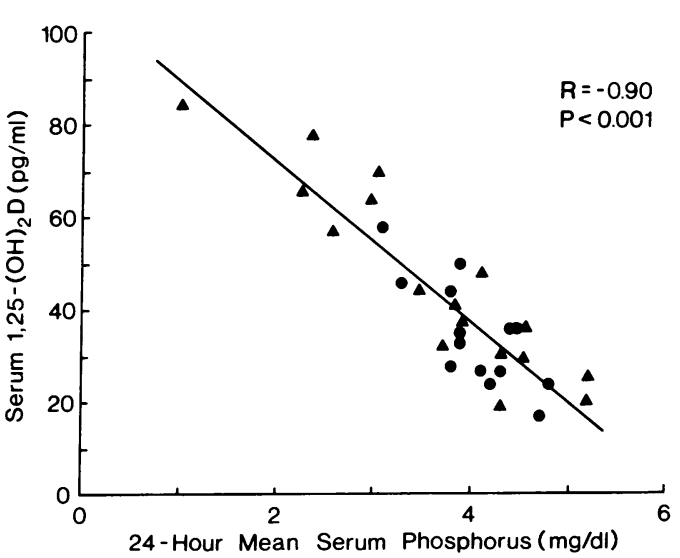

Figure 4. The relationship between serum levels of $1,25(\mathrm{OH})_{2} \mathrm{D}$ and 24-h mean serum levels of phosphorus in 12 normal men. Each point depicts data obtained during five separate study periods of 5-10 d duration, in which dietary phosphorus was maintained at either $<50,1,500$, or $>3,000 \mathrm{mg} / \mathrm{d}(\Delta)$ (data from reference 27); and 625 or $2,300 \mathrm{~g} / \mathrm{d}(\bullet)$ (this study). For each point depicted, the values of serum $1,25(\mathrm{OH})_{2} \mathrm{D}$ and phosphorus were calculated as in Fig. 3. 
measured, urinary excretion of $\operatorname{cAMP}(31,37,38)$. Conversely, in patients with moderate renal insufficiency, restriction of dietary phosphorus induces an increase in serum concentrations of $1,25(\mathrm{OH})_{2} \mathrm{D}$ despite inducing a decrease in the levels of iPTH (31). Thus, in a number of metabolic circumstances in humans, the effect of phosphorus on the renal production and serum concentration of $1,25(\mathrm{OH})_{2} \mathrm{D}$ can override that of parathyroid hormone.

The present studies do not address the question of the mechanism whereby dietary phosphorus-induced changes in extracellular concentration of phosphorus might effect changes in the activity of renal 1-hydroxylase. Regulation of the activity of this enzyme could depend on changes in extracellular concentration of phosphorus sensed by the renal tubule cell $(39,40)$, the cellular concentration of phosphorus (19), or some function of transcellular flux of phosphorus in the renal tubule cell. Whatever the mechanism, the currently observed diet-induced decrement in serum concentration of phosphorus that occurs during the daytime appears to be physiologically significant, though attended by no decrement in the morning fasting state. This observation highlights the importance of the integrated concentration of serum phosphorus throughout the day as a physiologic and perhaps pathophysiologic determinant of the production of $1,25(\mathrm{OH})_{2} \mathrm{D}$. For example, in patients with idiopathic hypercalciuria in whom morning fasting serum levels of phosphorus are either normal or only modestly decreased, their increased serum levels of $1,25(\mathrm{OH})_{2} \mathrm{D}(22,37,38)$ might be mediated by a decrement in phosphorus levels later during the day.

\section{Acknowledgments}

We thank Jessie Tatsuno and the nursing staff of the General Clinical Research Center for their expert patient care, Margaret Castro and Vivien Ho for expert technical assistance, and Andrea Marcellano for help in preparation of this manuscript.

This work was supported by grants from the National Institutes of Health (National Institute of Arthritis, Metabolism, and Digestive Diseases, DK-32631, the Division of Research Resources [General Clinical Research Center, 5 M01 RR 00079-26]), from the Veterans Administration, from the National Dairy Board, administered in cooperation with National Dairy Council, and by generous gifts from the Church and Dwight Corporation and the Emil Mosbacher, Jr. Foundation.

\section{References}

1. Fraser, D. R., and E. Kodicek. 1970. Unique biosynthesis by kidney of a biologically active vitamin D metabolite. Nature (Lond.). 228:764-766.

2. Gray, R. W., I. Boyle, and H. F. DeLuca. 1971. Vitamin D metabolism: the role of kidney tissue. Science (Wash. DC). 172:12321234.

3. Gray, R. W., J. L. Omdahl, J. G. Ghazarian, and H. F. DeLuca. 1972. 25-hydroxycholecalciferol-1-hydroxylase. J. Biol. Chem. 247:7528-7532.

4. Midgett, R. J., A. M. Spielvogel, J. W. Coburn, and A. W. Norman. 1973. Studies on calciferol metabolism. VI. The renal production of the biologically active form of vitamin $D, 1,25$-dihydroxycholecalciferol: species, tissue and subcellular distribution. J. Clin. En docrinol. \& Metab. 36:1153-1161.

5. Brunette, M. G., M. Chan, C. Ferriere, and K. D. Roberts. 1978. Site of $1,25(\mathrm{OH})_{2}$ vitamin $\mathrm{D}_{3}$ synthesis in the kidney. Nature (Lond.). 276:287-289.

6. Akiba, T., H. Endou, C. Koseki, and F. Sakai. 1980. Localization of 25 -hydroxyvitamin $D_{3}-1 \alpha$-hydroxylase activity in the mammalian kidney. Biochem. Biophys. Res. Commun. 94:313-318.
7. Kawashima, H., S. Torikai, and K. Kurokawa. 1981. Localization of 25-hydroxyvitamin $\mathrm{D}_{3} 1 \alpha$-hydroxylase and 24-hydroxylase along the rat nephron. Proc. Natl. Acad. Sci. USA. 78:1199-1203.

8. Garabedian, M., M. F. Holick, H. F. DeLuca, and I. T. Boyle. 1972. Control of 25-hydroxycholecalciferol metabolism by parathyroid glands. Proc. Natl. Acad. Sci. USA. 69:1673-1676.

9. Fraser, D. R., and E. Kodicek. 1973. Regulation of 25-hydroxycholecalciferol-1-hydroxylase activity in kidney by parathyroid hormone. Nat. New Biol. 241:163-166.

10. Henry, H. L., R. J. Midgett, and A. W. Norman. 1974. Regulation of 25-hydroxyvitamin $\mathrm{D}_{3}$-1-hydroxylase in vivo. J. Biol. Chem. 249:7584-7592.

11. Booth, B. E., H. C. Tsai, and R. C. Morris, Jr. 1977. Parathyroidectomy reduces 25 -hydroxyvitamin $\mathrm{D}_{3}-1 \alpha$-hydroxylase activity in the hypocalcemic vitamin D-deficient chick. J. Clin. Invest. 60:13141320.

12. Henry, H. L. 1979. Regulation of the hydroxylation of 25-hydroxyvitamin $\mathrm{D}_{3}$ in vivo and in primary cultures of chick kidney cells. J. Biol. Chem. 254:2722-2729.

13. Tanaka, Y., and H. F. DeLuca. 1984. Rat renal 25-hydroxyvitamin $\mathrm{D}_{3}-1$ - and 24-hydroxylases: their in vivo regulation. Am. J. Physiol. 246:E168-E173.

14. Booth, B. E., H. C. Tsai, and R. C. Morris, Jr. 1985. Vitamin D status regulates 25 -hydroxyvitamin $\mathrm{D}_{3}-1 \alpha$-hydroxylase and its responsiveness to parathyroid hormone in the chick. J. Clin. Invest. 75:155161.

15. Armbrecht, H. J., N. Wongsurawat, T. V. Zenser, and B. B. Davis. 1984. Effect of PTH and $1,25(\mathrm{OH})_{2} \mathrm{D}_{3}$ on renal $25(\mathrm{OH}) \mathrm{D}_{3}$ metabolism, adenylate cyclase, and protein kinase. Am. J. Physiol. 246:E102-E107.

16. Colston, K. W., I. M. A. Evans, L. Galante, I. MacIntyre, and D. W. Moss. 1973. Regulation of vitamin D metabolism: factors influencing the rate of formation of 1,25-dihydroxycholecalciferol by kidney homogenates. Biochem. J. 134:817-820.

17. Bikle, D. D., and H. Rasmussen. 1975. The ionic control of 1,25-dihydroxyvitamin $D_{3}$ production in isolated chick renal tubules. J. Clin. Invest. 55:292-298.

18. Trechsel, U., J.-P. Bonjour, and H. Fleisch. 1979. Regulation of the metabolism of 25 -hydroxyvitamin $D_{3}$ in primary cultures of chick kidney cells. J. Clin. Invest. 64:206-217.

19. Tanaka, Y., and H. F. DeLuca. 1973. The control of 25-hydroxyvitamin D metabolism by inorganic phosphorus. Arch. Biochem. Biophys. 154:566-574.

20. Baxter, L. A., and H. F. DeLuca. 1976. Stimulation of 25-hydroxyvitamin $\mathrm{D}_{3}-1 \alpha$-hydroxylase by phosphate depletion. J. Biol. Chem. 251:3158-3161.

21. Gray, R. W., and J. L. Napoli. 1983. Dietary phosphate deprivation increases 1,25 -dihydroxyvitamin $D_{3}$ synthesis in rat kidney in vitro. J. Biol. Chem. 258:1152-1155.

22. Gray, R. W., D. R. Wilz, A. E. Caldas, and J. Lemann, Jr. 1977. The importance of phosphate in regulating plasma $1,25-(\mathrm{OH})_{2}$ vitamin $D$ levels in humans: studies in healthy subjects, in calcium-stone formers and in patients with primary hyperparathyroidism. J. Clin. Endocrinol. \& Metab. 45:299-306.

23. Insogna, K. L., A. E. Broadus, and J. M. Gertner. 1983. Impaired phosphorus conservation and 1,25-dihydroxyvitamin D generation during phosphorus deprivation in familial hypophosphatemic rickets. J. Clin. Invest. 71:1562-1569.

24. Lufkin, E. G., R. Kumar, and H. Heath III. 1983. Hyperphosphatemic tumoral calcinosis: effects of phosphate depletion on vitamin D metabolism, and of acute hypocalcemia on parathyroid hormone secretion and action. J. Clin. Endocrinol. \& Metab. 56:1319-1322.

25. Maierhofer, W. J., R. W. Gray, and J. Lemann, Jr. 1984. Phosphate deprivation increases serum $1,25(\mathrm{OH})_{2}$ vitamin $\mathrm{D}$ concentrations in healthy men. Kidney Int. 25:571-575.

26. Portale, A. A., B. P. Halloran, M. M. Murphy, and R. C. Morris, Jr. 1986. Oral intake of phosphorus can determine the serum 
concentration of 1,25-dihydroxyvitamin $\mathrm{D}$ by determining its production rate in humans. J. Clin. Invest. 77:7-12.

27. Portale, A. A., B. P. Halloran, and R. C. Morris, Jr. 1987. Dietary intake of phosphorus modulates the circadian rhythm in serum concentration of phosphorus. J. Clin. Invest. 80:1147-1154.

28. Tieder, M., D. Modai, R. Samuel, R. Arie, A. Halabe, I. Bab, D. Gabizon, and U. A. Liberman. 1985. Hereditary hypophosphatemic rickets with hypercalciuria. $N$. Engl. J. Med. 312:611-617.

29. Carroll, M. D. 1983. Dietary intake source data: United States, 1976-80. In U.S. Department of Health and Human Services, National Center for Health Statistics (Pub. No. 83-1681). S. Abraham and C. M. Dresser, editors. Hyattsville, MD.

30. Shepard, R. M., R. L. Horst, A. J. Hamstra, and H. F. DeLuca 1979. Determination of vitamin $D$ and its metabolites in plasma from normal and anephric man. Biochem. J. 182:55-69.

31. Portale, A. A., B. E. Booth, B. P. Halloran, and R. C. Morris, Jr. 1984. Effect of dietary phosphorus on circulating concentrations of 1,25-dihydroxyvitamin $\mathrm{D}$ and immunoreactive parathyroid hormone in children with moderate renal insufficiency. J. Clin. Invest. 73:1580-1589.

32. Fiske, C. H., and Y. Subbarow. 1925. The colorimetric determination of phosphorus. J. Biol. Chem. 66:375-400.

33. Van Cauter, E. 1979. Method for characterization of 24-h temporal variation of blood components. Am. J. Physiol. 6:E255-E264.
34. Jenkins, G. M., and D. G. Watts. 1968. Spectral Analysis and its Applications. Vol. 5. Holden Day, Inc., Oakland, CA. 140-202.

35. Fuller, W. A. 1976. Introduction to Statistical Time Series. Vol. 7. John Wiley \& Sons, New York. 275-323.

36. Calvo, M. S., R. Kumar, and H. Heath III. 1988. Elevated secretion and action of serum parathyroid hormone in young adults consuming high phosphorus, low calcium diets assembled from common foods. J. Clin. Endocrinol. \& Metab. 66:823-829.

37. Van den Berg, C. J., R. Kumar, D. M. Wilson, H. Heath III, and L. H. Smith. 1980. Orthophosphate therapy decreases urinary calcium excretion and serum 1,25-dihydroxyvitamin D concentrations in idiopathic hypercalciuria. J. Clin. Endocrinol. \& Metab. 51:998-1001.

38. Broadus, A. E., J. S. Magee, L. E. Mallette, R. L. Horst, R. Lang, P. S. Jensen, J. M. Gertner, and R. Baron. 1983. A detailed evaluation of oral phosphate therapy in selected patients with primary hyperparathyroidism. J. Clin. Endocrinol. \& Metab. 56:953-961.

39. Biber, J., and H. Murer. 1985. Na-Pi cotransport in LLC-PK cells: fast adaptive response to $\mathrm{Pi}$ deprivation. Am. J. Physiol. 249:C430-C434.

40. Caverzasio, J., C. D. A. Brown, J. Biber, J.-P. Bonjour, and H. Murer. 1985. Adaptation of phosphate transport in phosphate-deprived LLC-PK cells. Am. J. Physiol. 248:F122-F127. 